Acta vet. scand. 1971, 12, 185-201.

From the Department of Reproductive Physiology and Pathology,

Veterinary College of Norway, Oslo.

\title{
STUDIES ON REPRODUCTION IN THE GOAT
}

VII. PREGNANCY AND THE DEVELOPMENT OF THE FOETUS AND THE FOETAL ACCESSORIES OF THE GOAT*)

By

Olav Lyngset

Information regarding pregnancy and the prenatal growth of the goat is very sparse. The only paper dealing with this subject appears to be that of Eaton (1952). He presents some figures of the weight and length of the goat foetuses at different ages. These goats were of the Toggenburger and common American breed, but only two of the foetuses were under 80 days of age.

Information regarding the normal length and weight of the goat kids at birth is almost non-existent. The only report found is that of Epstein \& Herz (1964).

Epstein \& Herz give the birth weight of some goat breeds in Israel. The differences between the breeds are great and correspond proportionately to the average body weight of the adults. Knowledge of the average length and weight at birth is necessary, together with measurements of foetuses at various ages, in order to obtain reliable figures for age determination. The question of age determination often arises in the cow (Gjesdal 1969) and should be of significance in the goat.

In a previous study some observations of the genital organs of the pregnant goat were made (Lyngset 1968b), but unfortunately no information regarding the animals before slaughtering was available.

In order to study the development of the goat foetus in more detail the investigations were continued in the present study.

*) The investigation was financially supported by the Agricultural Research Council of Norway and Statens Veterinærvitenskapelige Forskningsfond. 


\section{MATERIAL AND METHODS}

Eighteen goats of the common Norwegian breed were bred artificially with deep-frozen semen (Andersen 1969). The goats were of different age and size, the body weight varying between 26.0 and $51.5 \mathrm{~kg}$ with an average of about $37.5 \mathrm{~kg}$. Pregnancies in the early stages were detected radiographically (Birkeland $\&$ Lyngset 1969). At different stages of pregnancy one goat (26, 31, 45,130 days), and a pair of goats $(68,75,90,105,140$ and 145 days) were ovariohysterectomized. The animals were starved for 24 hrs. prior to surgery. No premedication was given and the surgery was performed under ether anaesthesia. An incision was made in linea alba from the umbilicus to the udder.

After removing the uterus and the ovaries the organs were placed in crushed ice until examination took place. On examination the ovaries were handled in the same way as described in a previous report (Lyngset 1968a). The corpora lutea were enucleated before measuring the weight and diameter. The uterus was cut between the caruncles and the foetal fluid measured. An attempt was made to separate the amniotic and allantoic fluid. The foetal membranes and the foetus were inspected and the weight and length of the foetus were measured. Length measurements were taken according to the procedure followed in the previous investigations (Lyngset 1968b). The weight of the foetuses was measured on a Mettler scale.

The measurements of the kids at birth were carried out in two large goat herds for two successive years and comprise a total of $\mathbf{4 8 0}$ kids. The Norwegian breed of goat is of medium size; the weight of adult males averages $60-70 \mathrm{~kg}$ and of the females $40-50 \mathrm{~kg}$. Management was good in the herds and the level of nutrition was high and varied little from herd to herd.

Measurements of weight and length were taken as soon as possible after the kids were born and had been dried. The herds were inspected every second hour day and night.

The length of the kids was measured from the forehead to the fixation of the tail with the animal lying on its side. Care was taken to avoid stretching. The method of measurement was the same as the one used on the goat foetuses.

The weight was measured with a steelyard with the kid sitting in a bucket. The time elapse between birth and measurement was always within the range of $4 \mathrm{hrs}$.

Some figures obtained in a previous investigation (Lyngset 
$1968 \mathrm{~b})$, concerning the size of the corpus luteum in relation to the number of foetuses, have been incorporated in this investigation as well as one goat that was slaughtered on the 36th day of pregnancy.

\section{General observations}

\section{RESULTS}

By the 26th day of pregnancy the foetus occupies almost all of the space in the amniotic cavity, and the amount of amniotic fluid is scant. The cotyledons are clearly visible. At 30 days the amniotic sac has grown relatively more than the foetus, and there is more room for the foetus in the amniotic cavity (Figs. 1 and 2).

At 45 days the dimensions of the uterus are $16 \times 7 \mathrm{~cm}$ (Fig. 3 ). The foetus is still almost transparent, the ribs and the viscera visible. The foundation of the ear is marked though not prominent. The eyes are not covered with eyelids. Hair follicles are visible around the 60th day. On especially one of the foetuses examined at this age the hair growth was very distinct.

At 75 days the uterus had increased in size, the dimensions being $25 \times 13 \mathrm{~cm}$, the largest caruncles measuring $5 \times 2.5 \mathrm{~cm}$. The smallest caruncles are always circular, but as they grow, they become more elongated in shape. No longer are the ribs and the columna of the foetus visible, nor are the blood vessels except for the proximal part of V. jugularis. At this age there are also hair follicles visible around the mouth.

From the 75 th to the 90 th day the foetus increases in size, but there is little increase in the distribution and growth of the hair. On a male foetus the testicles could easily be palpated in the scrotum which measured $2 \mathrm{~cm}$ in length.

In the period from the 90 th to the 115th day, hair growth has increased, and at about $\mathbf{1 1 0}$ days of age the entire body of the foetus is covered with hair. The fur coat is thick especially on the head and on the back. The lengthwise growth of the hair still continues and seems to be completed at about 120 days of age. After this time there is little further growth of hair.

At an age of about $\mathbf{1 3 0}$ days the eyes begin to open. The eyes of the foetus examined on the 130th day were half open and at 140 days the eyes were completely open. The teeth did not errupt in foetal life. Even at $\mathbf{1 4 5}$ days the teeth of the foetuses were covered with epithelium. 


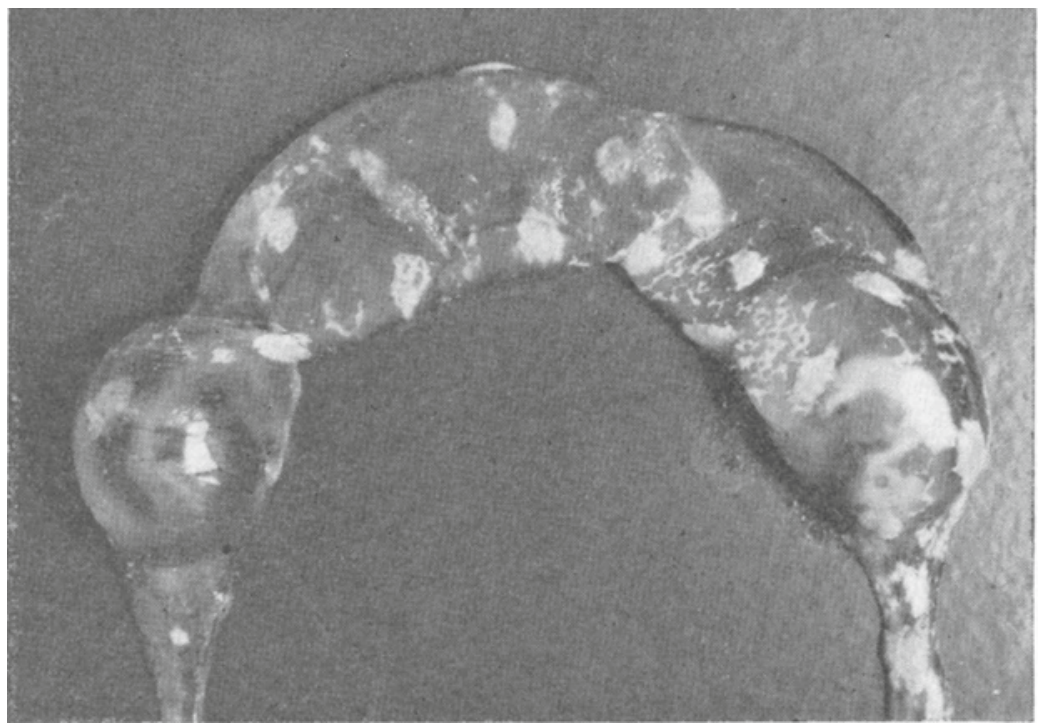

Figure 1. A pair of twin foetuses, 36 days of age, in their foetal membranes. The size of the foetuses at this age is $1.6-2 \mathrm{~cm}$ measured as the total length.

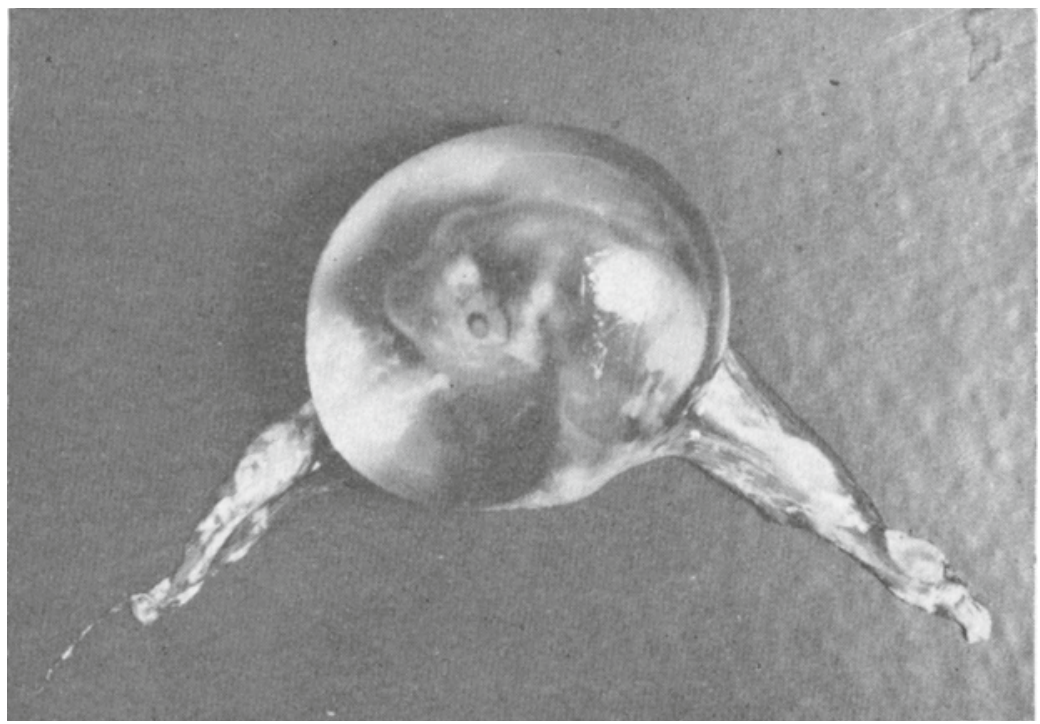

Figure 2. A foetus 36 days of age, surrounded by its amniotic fluid and -membrane. 

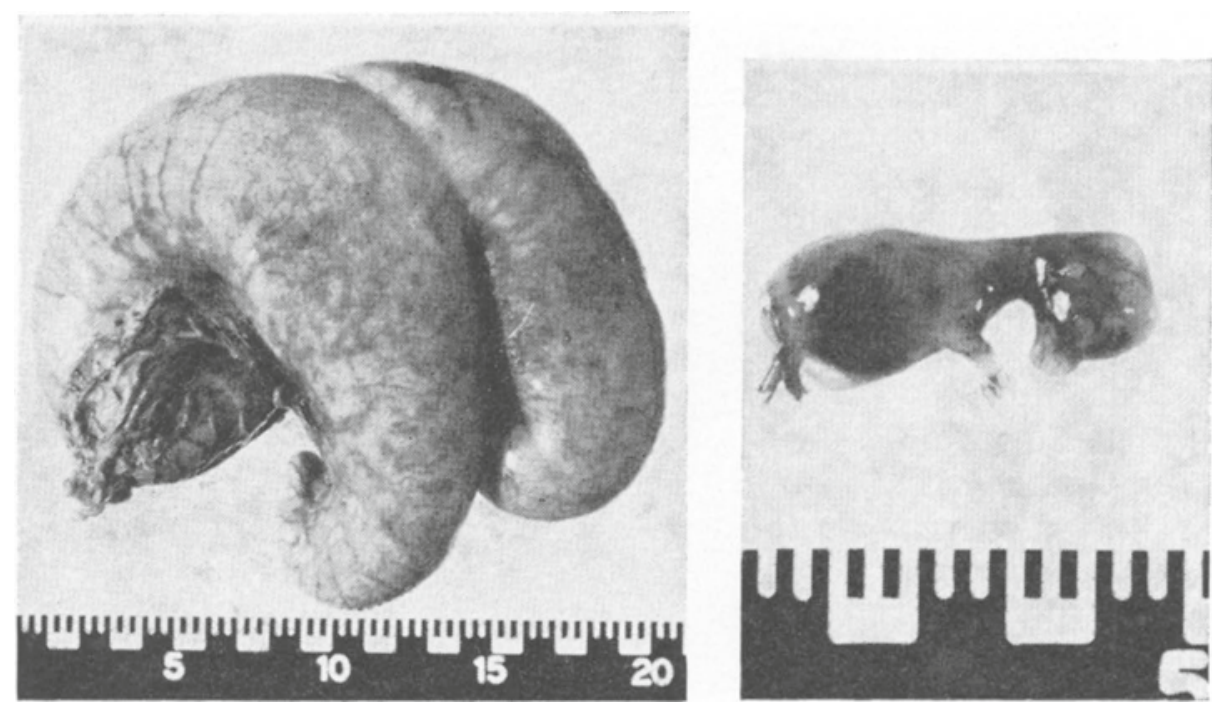

F i g u r e 3. The uterus of a goat on the 45th day of pregnancy, beside one of the three foetuses $(4.7 \mathrm{~cm})$ it contained.

In some cases white spots $1-3 \mathrm{~mm}$ in diameter can be seen on the inside of the amnion, projecting $1-2 \mathrm{~mm}$ on the surface (Fig. 4). In some cases this phenomenon is lacking, in others the spots are numerous. These spots have been found to be epithelial proliferations (Fig. 5).

As previously reported (Lyngset $1968 \mathrm{~b}$ ), a marked asymmetry of the two uterine horns can be seen even in cases of twin pregnancy with one foetus in each uterine horn. This was also found in the present investigation. A white network was observed in the allantochorion among the cotyledons (Fig. 6). It appeared to be a precipitation of a white substance on the epithelium. Due to an accident, a planned histological examination could not be carried out. Thus it is not possible to state whether or not this was a kind of the epithelial proliferations as found in the amnion. From about the 90th day of pregnancy the foetus was partly covered with a yellow layer of fibrinous mucus. The mucus had a strong yellow colour and was constantly present from this time until birth.

The colour and consistency of the foetal fluid changed with advancing pregnancy. In the beginning both the amniotic and the allantoic fluid were colourless and watery in appearance. With increasing age the amniotic fluid became slightly more 


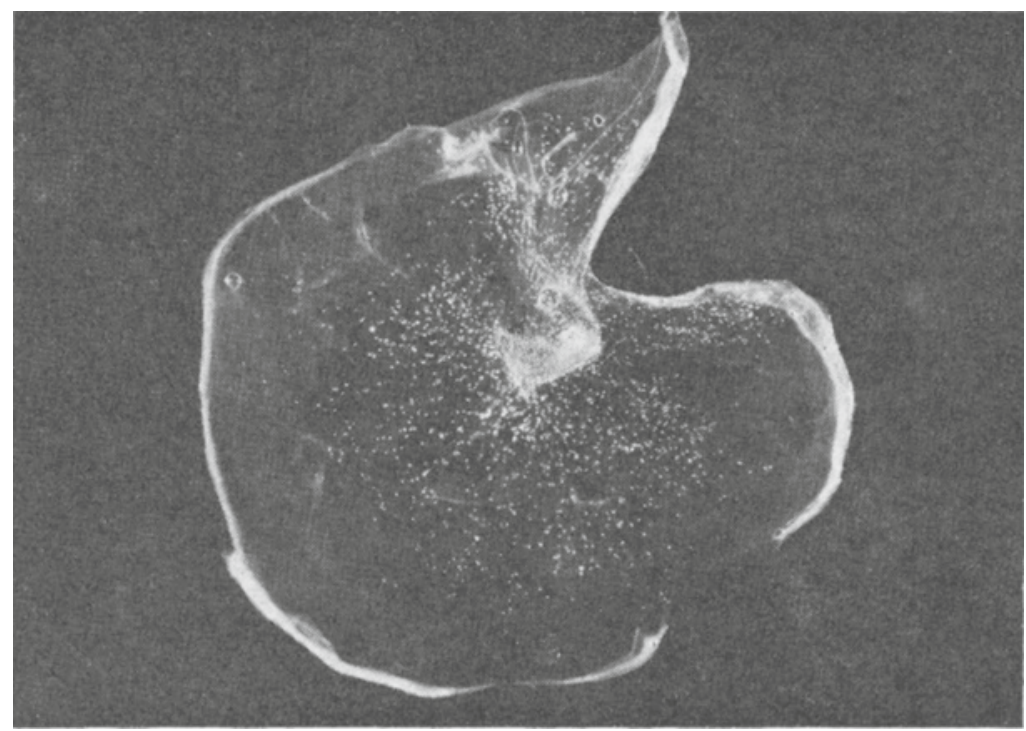

Figure 4. The amnion of a goat with epithelial proliferation.

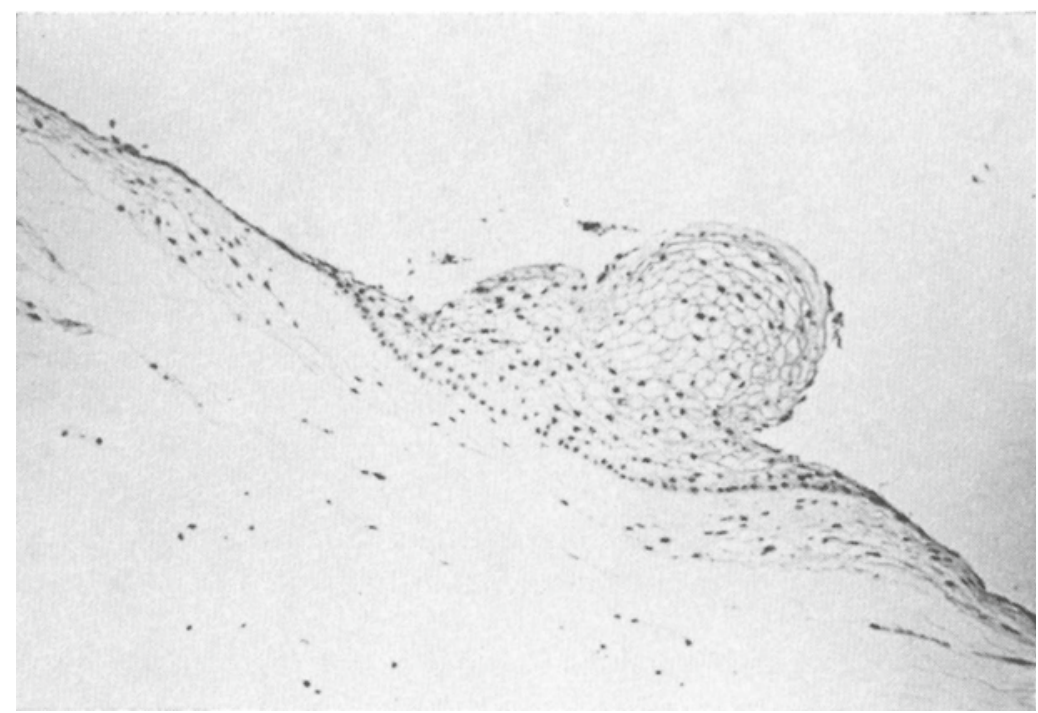

Figure 5. Microphotograph showing proliferation of the amniotic epithelium of the goat. 


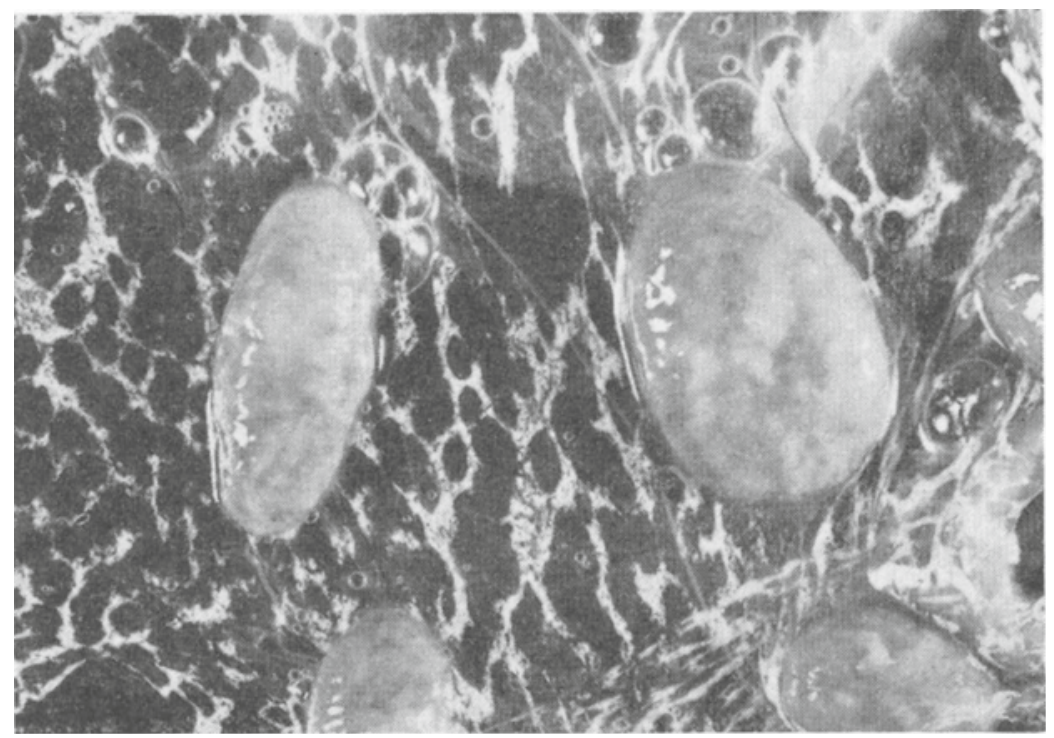

Figure 6. Allantochorion and the cotyledons of the goat (see text).

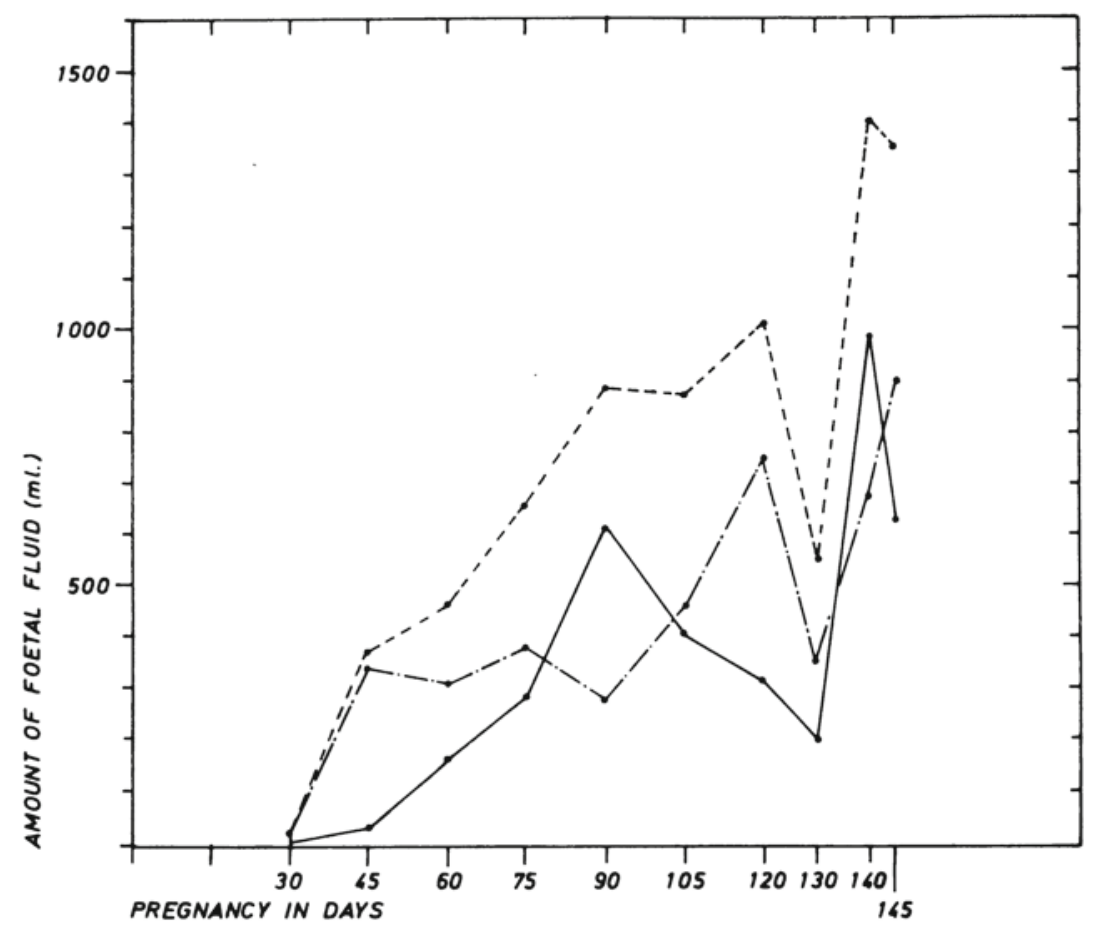

Figure 7. Variation in the amount of foetal fluid with increasing age of the foetus.

..... total amount of fluid

-.-.- allantoic fluid

amniotic fluid 
yellow in colour and more viscous. At about 90 days the colour was usually strongly yellow, but could be paler. The viscosity increased steadily, and from 90 days onward the fluid coagulated easily when exposed to air. After 130 days "capromanes", resembling natural sponge, were seen in the fluid. From this time onward meconium was also seen regularly.

In the beginning the allantoic fluid was colourless and had a water-like appearance. The colour changed to yellow and light brown and the fluid became turbid as the pregnancy developed.

Table 1. Variation in the amount of foetal fluid with increasing age of the foetus $(\mathrm{ml})$.

\begin{tabular}{|c|c|c|c|c|c|}
\hline $\begin{array}{c}\text { Days of } \\
\text { pregnancy }\end{array}$ & $\begin{array}{l}\text { Amniotic } \\
\text { fluid, } \\
\text { variation }\end{array}$ & $\begin{array}{l}\text { Amniotic } \\
\text { fluid, } \\
\text { mean }\end{array}$ & $\begin{array}{l}\text { Allantoic } \\
\text { fluid, } \\
\text { variation }\end{array}$ & $\begin{array}{l}\text { Allantoic } \\
\text { fluid, } \\
\text { mean }\end{array}$ & $\begin{array}{c}\text { Total } \\
\text { amount } \\
\text { of foetal } \\
\text { fluid, } \\
\text { mean }\end{array}$ \\
\hline 30 & $\begin{array}{l}2 \\
5\end{array}$ & 3.5 & $\begin{array}{l}40 \\
10 ?\end{array}$ & 25 & 28.5 \\
\hline 45 & $\begin{array}{c}34,22, \\
36\end{array}$ & 30.7 & & 340 & 370.7 \\
\hline 60 & $\begin{array}{c}100 \\
160,210\end{array}$ & 156.7 & $\begin{array}{l}210 \\
400\end{array}$ & 305 & 461.7 \\
\hline 75 & $\begin{array}{l}360 \\
200\end{array}$ & 280 & $\begin{array}{l}260 \\
500\end{array}$ & 380 & 660 \\
\hline 90 & $\begin{array}{l}530 \\
700\end{array}$ & 615 & $\begin{array}{l}230 \\
325\end{array}$ & 277.5 & 892.5 \\
\hline 105 & $\begin{array}{c}400,540 \\
290\end{array}$ & 410 & $\begin{array}{l}680 \\
240\end{array}$ & 460 & 870 \\
\hline 120 & $\begin{array}{l}300 \\
330\end{array}$ & 315 & $\begin{array}{l}760 \\
740\end{array}$ & 750 & 1065 \\
\hline 130 & & 200 & & 350 & 550 \\
\hline 140 & 950,1030 & 990 & $\begin{array}{c}750,600 \\
1140^{*}\end{array}$ & 675 & 1402.5 \\
\hline 145 & & 630 & $1250^{*}$ & 800 & 1340 \\
\hline
\end{tabular}

* total amount of foetal fluid, 


\section{Results of the measurements}

The amount of amniotic and allantoic fluid and the total amount of foetal fluid in relation to the foetal growth are shown in Table 1. At the end of the pregnancy it was difficult to separate the amniotic and allantoic fluid. Therefore, in a couple of cases, only the total amount of fluid was recorded. In Fig. 7 the variation in the amount of foetal fluid is shown graphically. One of the main purposes of this investigation was to record the growth in length and the weight of the foetuses throughout pregnancy. This is shown in Table 2. Weight measurements for the three earliest stages of pregnancy were, because of an accident, lost. In Fig. 8 the lengths are presented graphically in relation to the age.

The length and weight of the goat kids at birth are shown in Table 3. In Table 4 the variation in the birth length and weight

Table 2. Development of length and weight of the foetus with increasing age $(\mathrm{cm}$ and $\mathrm{g})$.

\begin{tabular}{|c|c|c|c|c|c|}
\hline \multirow{2}{*}{$\begin{array}{l}\text { Days of } \\
\text { pregnancy }\end{array}$} & \multirow{2}{*}{$\begin{array}{l}\text { Sex of } \\
\text { foetus }\end{array}$} & \multicolumn{2}{|c|}{ Length of foetus } & \multicolumn{2}{|c|}{ Weight of foetus } \\
\hline & & variation & mean & variation & mean \\
\hline 30 & & $\begin{array}{l}1.2 \\
1.6\end{array}$ & 1.4 & & \\
\hline 45 & $\sigma^{x} \sigma^{x} \sigma^{x}$ ? & $4.3,3.8,4.7$ & 4.3 & & \\
\hline 60 & $\begin{array}{l}0^{x} \\
\text { \& }\end{array}$ & $\begin{array}{c}9.0 \\
9.6,9.5\end{array}$ & 9.4 & & \\
\hline 75 & $\begin{array}{l}q \\
q\end{array}$ & $\begin{array}{l}13.7 \\
14.0\end{array}$ & 13.9 & $\begin{array}{l}110 \\
115\end{array}$ & 112.5 \\
\hline 90 & $\sigma^{x}$ & $\begin{array}{l}19.5 \\
21.3\end{array}$ & 20.4 & $\begin{array}{l}375 \\
420\end{array}$ & 397.5 \\
\hline 105 & $\begin{array}{l}\sigma^{x}+9 \\
\sigma^{x}\end{array}$ & $\begin{array}{l}25.0,24.5 \\
26.0\end{array}$ & 25.2 & & 780.0 \\
\hline 120 & $\begin{array}{l}q \\
\sigma^{x}\end{array}$ & $\begin{array}{l}32.0 \\
34.0\end{array}$ & 33.0 & $\begin{array}{l}1625 \\
1715\end{array}$ & 1670.0 \\
\hline 130 & 우요 & & 36.5 & & 2227.0 \\
\hline 140 & $\begin{array}{l}\sigma^{x} \sigma^{x} \\
\varnothing\end{array}$ & $\begin{array}{c}39.0,40.0 \\
42.0\end{array}$ & 40.3 & $\begin{array}{c}2370.0,2570.0 \\
2715.0\end{array}$ & 2551.7 \\
\hline 145 & $\begin{array}{l}\text { क } \\
\sigma^{x}\end{array}$ & $\begin{array}{l}42.0 \\
44.0\end{array}$ & 43.0 & $\begin{array}{l}2642.0 \\
3192.0\end{array}$ & 2917.0 \\
\hline
\end{tabular}




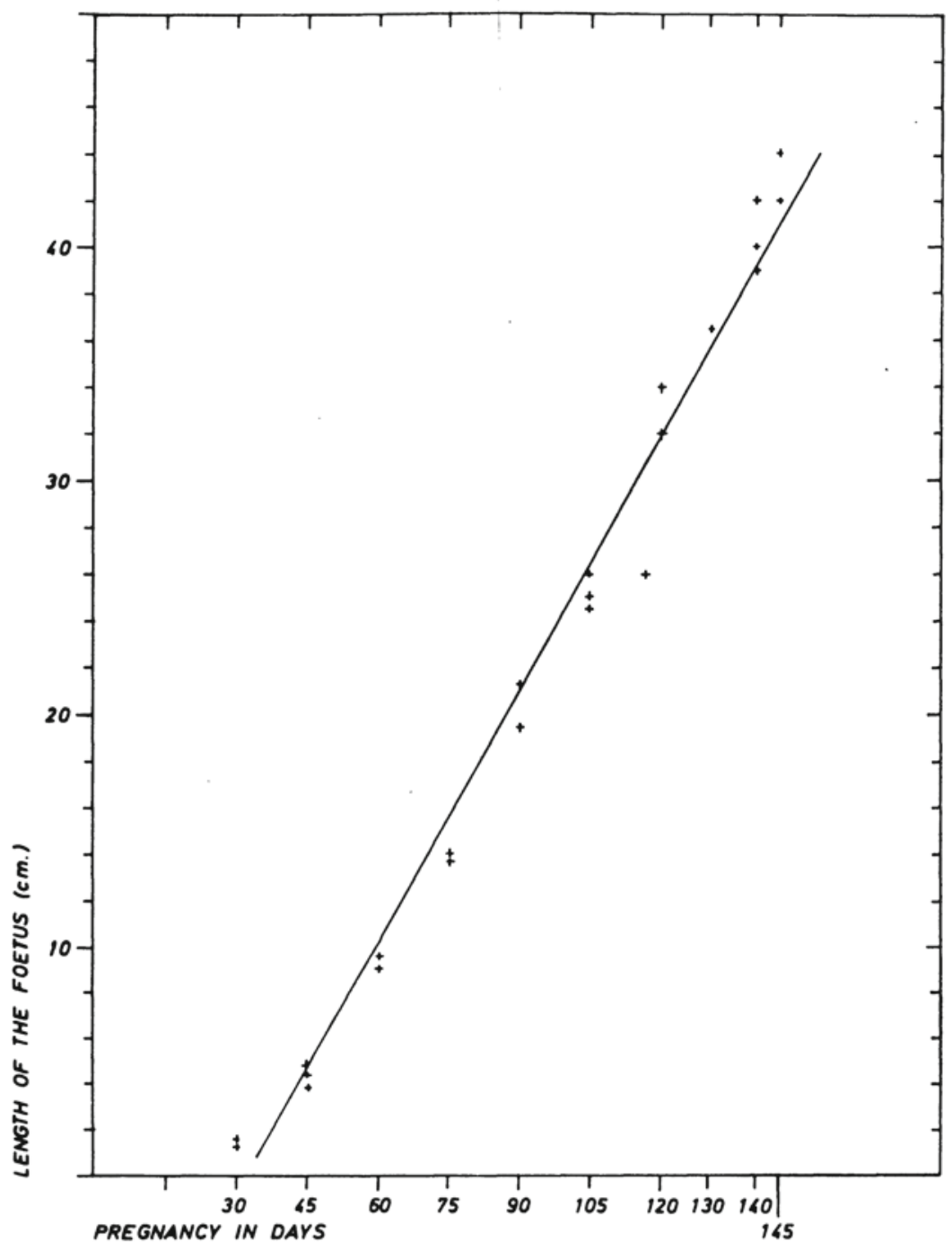

Figure 8 . Length-growth of the foetus with increasing age.

with the increasing age of the dam is shown. The male goat does not seem to have any influence on the birth weight and length of the kids (Table 5 ).

In Table 6 the size - diameter and weight - of the corpus luteum graviditatis and its development with the increasing age of the foetuses are shown. The variation in the size of the corpus luteum graviditatis in relation to the number of foetuses and corpora lutea is shown in Fig. 9. 
T a ble 3. Length and weight of the goat kids at birth ( $\mathrm{cm}$ and $\mathrm{kg}$ ).

\begin{tabular}{|c|c|c|c|c|c|c|}
\hline & $\begin{array}{c}\text { No. of } \\
\text { kids }\end{array}$ & $\begin{array}{l}\text { Mean } \\
\text { length }\end{array}$ & Variation & $\begin{array}{l}\text { No. of } \\
\text { kids }\end{array}$ & $\begin{array}{c}\text { Mean } \\
\text { weight }\end{array}$ & Variation \\
\hline All kids & 470 & 42.06 & $31-50$ & 480 & 2.81 & $1.50-4.30$ \\
\hline $0^{x}$ & 262 & 42.41 & $31-50$ & 269 & 2.90 & $1.50-4.30$ \\
\hline 우 & 200 & 41.66 & $34-48$ & 203 & 2.62 & $1.65-3.90$ \\
\hline Single & 185 & 42.55 & $35-50$ & 192 & 3.02 & $2.00-4.30$ \\
\hline Single $\sigma^{x}$ & 104 & 43.01 & $35-50$ & 111 & 3.14 & $2.10-4.30$ \\
\hline Single $ᄋ$ & 80 & 42.00 & $34-48$ & 81 & 2.88 & $2.00-3.70$ \\
\hline Twins & 276 & 41.83 & $31-49$ & 282 & 2.69 & $1.50-4.00$ \\
\hline$\sigma^{x} \sigma^{x}$ & 72 & 42.09 & $35-49$ & 72 & 2.83 & $1.65-3.50$ \\
\hline 우 우 & 38 & 41.10 & $36--47$ & 38 & 2.62 & $1.70-3.80$ \\
\hline$\sigma^{x}$ 우 & 158 & 41.87 & $31-49$ & 160 & 2.73 & $1.50-4.00$ \\
\hline $0^{+}$ & 80 & 42.24 & $31-49$ & 80 & 2.89 & $1.50-4.00$ \\
\hline 우 & 78 & 41.54 & $34-48$ & 80 & 2.57 & $1.65-3.90$ \\
\hline
\end{tabular}

T a b le 4. Variation in the birth length and weight of the kids with increasing age of the goat $(\mathrm{kg}$ and $\mathrm{cm})$.

\begin{tabular}{lccccccc}
\hline $\begin{array}{c}\text { Age of } \\
\text { goat }\end{array}$ & $\begin{array}{c}\text { No. of } \\
\text { births }\end{array}$ & $\begin{array}{c}\text { No. of } \\
\text { kids }\end{array}$ & $\begin{array}{c}\text { Mean } \\
\text { length }\end{array}$ & Variation & $\begin{array}{c}\text { Mean } \\
\text { weight }\end{array}$ & Variation & $\begin{array}{c}\text { Kids } \\
\text { per } \\
\text { birth }\end{array}$ \\
\hline 1st birth & 72 & 88 & 41.28 & $35-50$ & 2.75 & $1.65-3.75$ & 1.22 \\
2nd birth & 39 & 58 & 40.29 & $31-45$ & 2.76 & $1.50-4.10$ & 1.49 \\
3rd birth & 35 & 61 & 40.39 & $35-49$ & 2.77 & $1.80-4.30$ & 1.74 \\
4th birth & 22 & 27 & 42.23 & $26-48$ & 3.11 & $2.60-3.90$ & 1.32 \\
5th birth & 28 & 44 & 41.00 & $37-45$ & 2.85 & $1.90-4.00$ & 1.57 \\
6th birth & 13 & 19 & 41.21 & $38-46$ & 3.03 & $2.30-3.40$ & 1.46 \\
\hline
\end{tabular}

T a b l e 5. The influence of the male goat on fertility and birth weight and birth length of the offspring $(\mathrm{kg}$ and $\mathrm{cm})$.

\begin{tabular}{|c|c|c|c|c|c|c|c|c|c|c|c|c|}
\hline $\begin{array}{l}\text { Male } \\
\text { goat }\end{array}$ & $\begin{array}{l}\text { No. of } \\
\text { births }\end{array}$ & $\begin{array}{l}\text { Single } \\
\text { births }\end{array}$ & $\begin{array}{l}\text { Twin } \\
\text { births }\end{array}$ & $\begin{array}{l}\text { Triplet } \\
\text { births }\end{array}$ & $\begin{array}{l}\text { No. of } \\
\text { kids }\end{array}$ & $\underset{\mathbf{k i d}}{\sigma^{x}}$ & $\underset{\text { kid }}{\stackrel{9}{1}}$ & $\underset{\text { kid }}{\stackrel{0}{x}}$ & $\begin{array}{c}\text { Mean } \\
\text { weight }\end{array}$ & Variation & $\begin{array}{l}\text { Mean } \\
\text { length }\end{array}$ & Variation \\
\hline I Kvikk & 41 & 29 & 12 & 一 & 53 & 31 & 21 & 1 & 3.03 & $2.1-4.1$ & 40.23 & $36-46$ \\
\hline II Bamse & 28 & 16 & 11 & 1 & 41 & 17 & 22 & 2 & 2.79 & $2.0-3.6$ & 39.89 & $34-47$ \\
\hline III Beatles & 14 & 6 & 8 & 一 & 22 & 14 & 8 & 一 & 2.80 & $2.2-3.1$ & 40.62 & $36-44$ \\
\hline IV Fridar & 13 & 8 & 5 & - & 17 & 12 & 5 & - & 2.84 & $2.0-3.6$ & 40.68 & $37-45$ \\
\hline
\end{tabular}


T a b l e 6. Variation in the diameter and weight of the corpus luteum with increasing age of the foetus ( $\mathrm{cm}$ and $\mathrm{g}$ ).

\begin{tabular}{|c|c|c|c|c|}
\hline \multirow{2}{*}{$\begin{array}{l}\text { Days of } \\
\text { pregnancy }\end{array}$} & \multicolumn{2}{|c|}{ Corpus luteum diameter } & \multicolumn{2}{|c|}{ Corpus luteum weight } \\
\hline & variation & mean & variation & mean \\
\hline 30 & 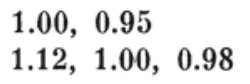 & 1.01 & $\begin{array}{l}0.40,0.31 \\
0.47,0.35,0.48\end{array}$ & 0.40 \\
\hline 45 & $0.90,1.00,1.00$ & 0.97 & $0.35,0.39,0.26$ & 0.33 \\
\hline 60 & $\begin{array}{l}1.05,1.05,1.00 \\
1.60,1.00\end{array}$ & 1.14 & $\begin{array}{l}0.65,0.51,0.33 \\
1.43,0.46\end{array}$ & 0.68 \\
\hline 75 & $\begin{array}{l}1.28 \\
1.38\end{array}$ & 1.33 & $\begin{array}{l}0.73 \\
0.97\end{array}$ & 0.85 \\
\hline 90 & $\begin{array}{l}1.55 \\
1.23,1.35\end{array}$ & 1.38 & $\begin{array}{l}1.37 \\
0.94,1.07\end{array}$ & 0.79 \\
\hline 105 & $\begin{array}{l}1.27,1.10 \\
1.45\end{array}$ & 1.24 & $\begin{array}{l}0.74,0.75 \\
0.92\end{array}$ & 0.80 \\
\hline 120 & $\begin{array}{l}1.60 \\
1.50\end{array}$ & 1.55 & $\begin{array}{l}1.16 \\
0.92\end{array}$ & 1.04 \\
\hline 130 & 1.50 & 1.50 & 0.91 & 0.91 \\
\hline 140 & $\begin{array}{l}1.50,1.50 \\
1.60\end{array}$ & 1.53 & $\begin{array}{ll}0.83, & 0.86 \\
1.04 & \end{array}$ & 0.91 \\
\hline 145 & $\begin{array}{l}1.40 \\
1.70,1.70\end{array}$ & 1.60 & $\begin{array}{l}0.92 \\
0.97,1.11\end{array}$ & 1.00 \\
\hline
\end{tabular}

\section{DISCUSSION}

The epithelial proliferations on the inside of the amniotic membrane have been described earlier (Richter \& Götze 1960). The aetiology and significance of this phenomenon is unknown. It is probably to be considered as a normal but inconstant feature. It is also impossible to explain the significance of the white network on the allantochorion in between the cotyledons. Meconium was seen regularly in the amniotic fluid from about 130 days onward. According to Richter \& Götze meconium should only be seen in the amniotic fluid when the foetus is damaged in the uterus, or is affected by an inherited disease.

The total amount of foetal fluid seems to increase throughout pregnancy. From a total amount of about $30 \mathrm{ml}$ at 30 days it increases to about $1,400 \mathrm{ml}$ at partus in a single pregnancy. Richter \& Götze report 500-1,200 ml amniotic fluid and 500$1,500 \mathrm{ml}$ allantoic fluid as normal at partus for the small rumi- 


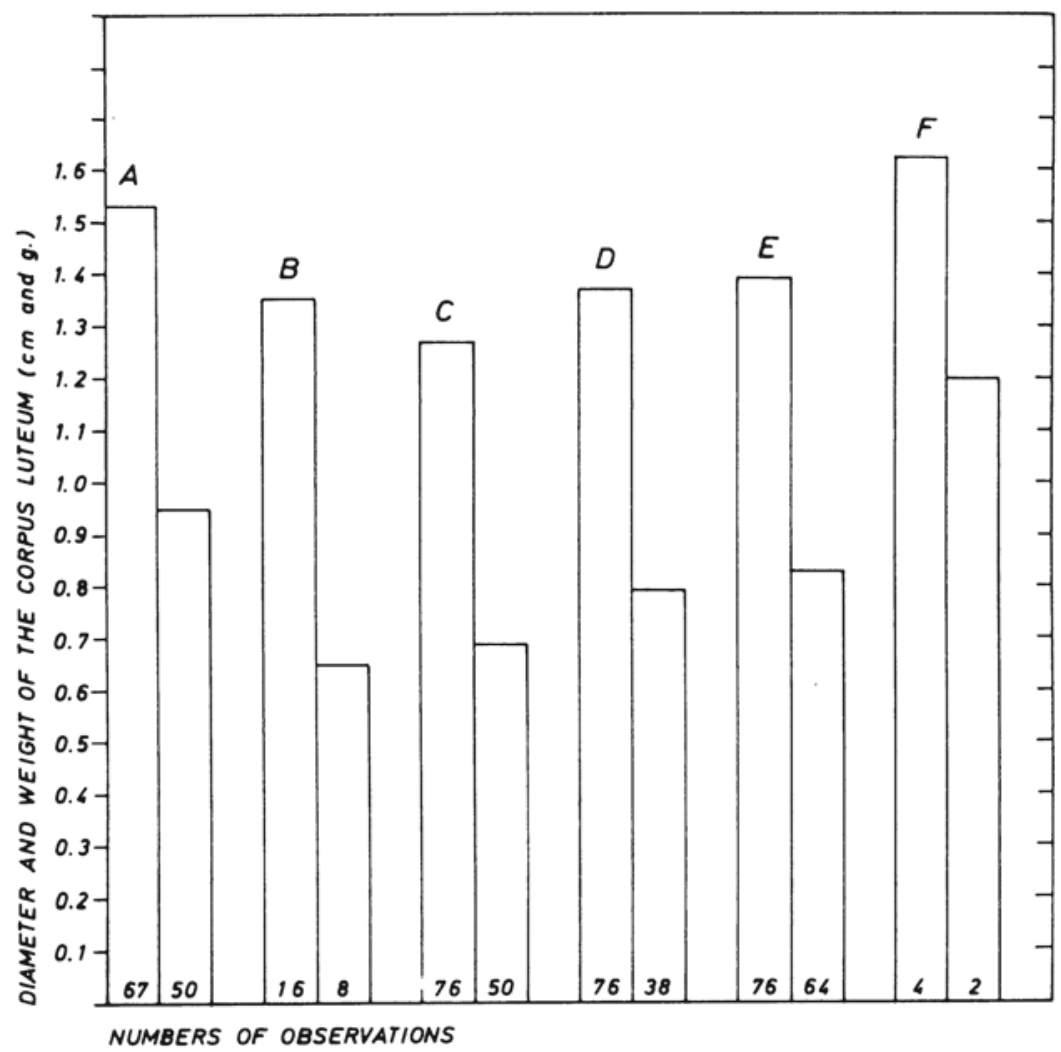

Figure 9. Variation in the size of the corpus luteum graviditatis in relation to the number of foetuses and the number of corpora lutea (c. l.); left column: diameter; right column: weight.
$A=$ One c.l. and one foetus
$\mathrm{B}=$ One c.l. in each ovary and one foetus
$\mathrm{C}=$ Two c.l. in the same ovary and one foetus
$\mathrm{D}=$ One c.l. in each ovary and two foetuses
$\mathrm{E}=$ Two c.l. in the same ovary and two foetuses
$\mathrm{F}=$ One c.l. and two foetuses

nants. From this investigation it can be stated that $600-1,000$ $\mathrm{ml}$ amniotic fluid per foetus is normal for a goat at partus. As for the allantoic fluid, this will vary between $600-1,100 \mathrm{ml} \mathrm{de}-$ pending on the number of foetuses, although variation with the number of foetuses is surprisingly small. There is also a discrepancy in the observations of this investigation and the one of Richter \& Götze as far as the consistency of the foetal fluid is concerned. While the authors mentioned find the amniotic 
fluid water-like (wässerig), this is only true in the earliest stage of the pregnancies. As mentioned previously, as pregnancy progresses the fluid becomes viscous and coagulates easily when exposed to air.

In early stages of pregnancy the allantoic fluid is greatest in volume, and the increase in volume is also greatest for this fluid the first two to three months. Later on the increase in the amniotic fluid is the greatest. At the end of pregnancy the amount of amniotic fluid per foetus is about the same as the total amount of allantoic fluid.

Measurements of the length of the foetuses were undertaken from the 26th day $-1.2 \mathrm{~cm}$, to the $145 \mathrm{th}$ day - mean $43 \mathrm{~cm}$. The lengthwise growth rate from 30 days and onward is approximately linear and differs appreciably from the curve given by Eaton (1952) for the Toggenburger goat and the goats of the common American breed. From the curve in Fig. 8 the age can be calculated from the 30th day when the length is known. These will, of course, be only approximate values because of the inexact linearity of the curve and the differences that will occur in the length measurements.

As mentioned before the weight measurements of the foetuses at the three earliest stages of pregnancy were accidentally lost. The weight gain was especially great between the 105th and 120th day, but also between the 120th and 130th day.

In the period between the 105th and 120th day the weight gain was $60 \mathrm{~g}$ per day.

The weight of the kids at birth is, of course, influenced by many factors, for instance: Breed, number at birth and the nutritional level of the mother goat. In all of the kids the difference between the male and female was $0.28 \mathrm{~kg}$ which amounts to $10 \%$ of the average weight of all kids. The heaviest kids were the singly born male kids, averaging $3.14 \mathrm{~kg}$. The difference between singly born male and female kids was $0.26 \mathrm{~kg}$ or $8.28 \%$. In twin births with one kid of each sex the difference between the sexes was $0.32 \mathrm{~kg}$. The average single kid weighed $0.33 \mathrm{~kg}$ more than the average twin kid.

Epstein \& Herz (1964) found a definite tendency for the kids from a pair of twins of different sexes to be heavier than the kids from a pair of twins of the same sex. There seems to be a similar trend in the breed under review. 
The weight of the kids of the Norwegian breed is mostly comparable to the Sannen breed. Compared with, for instance, the Appenzeller breed, the Norwegian breed is small, the difference in the birth weight of male single kids being $0.86 \mathrm{~kg}$. The birth weight can be of great value in determining the age of the kid. The reliability of the length measurements can be questioned (Gjesdal 1969). Stretching of the animal can be difficult to avoid and the same reservations can be made as for the measurements of the genital organs of the goat (Lyngset 1968a). If reproducible figures are to be obtained the measurements should be taken by only one person.

In Table 4 the variation in the birth length and weight with increasing age of the goat is shown. There seems to be a trend to an increasing body weight with increasing age of the dam. There is also an increase of twin births with increasing age. It is conceivable that the increasing incidence of twins will mask an increase in birth weight.

There seems to be no influence of the male goat on the birth weight and length of the kids. When the birth weight is considered in relation to the sex of the kid and the frequency of single and twin births, no significant difference is found between the males.

It has previously been found that the corpus luteum increases in size with the increasing size of the foetus (Lyngset 1968b). This observation is confirmed by the present investigation. There appears to be an increase in both the diameter and weight of the corpus luteum throughout pregnancy. This is in contrast to the secretory activity. It has recently been shown that the amount of progesterone in the ovarian vein reached a maximum at about 90 days $(3,100 \mathrm{ng} / \mathrm{ml})$ followed by a gradual decline at partus $(600 \mathrm{ng} / \mathrm{ml}$ ) (Blom \& Lyngset 1971). The increase in the size of the corpus luteum from the 90 th day and onward is not accompanied by an equal increase in progesterone secretion.

There seems to be a tendency for the corpus luteum to increase in size in relation to the number of foetuses (Fig. 9). The figure shows that when there is only one corpus luteum to support pregnancy, it is on the average larger than when there are two corpora lutea and only one foetus. In the few cases when there are two foetuses, but only one corpus luteum, this is also large, which could be expected since this corpus luteum alone is producing the hormone for two foetuses. 


\section{REFERENCES}

Andersen, K.: Insemination with frozen semen in goats. Nord. Vet.Med. 1969, 21, 625-628.

Birkeland, R. \& O. Lyngset: Røntgenologisk drektighetsdiagnostik hos geit. (Radiographic pregnancy diagnosis in goats). Nord. Vet.Med. 1969, 21, 629-634.

Blom, A. K. \& O. Lyngset: Plasma progesterone levels in goats during pregnancy measured by the CBG- (corticosteroid-binding globulin) method. Acta endocr. (Kbh.) 1971, 66, 471-477.

Eaton, $O$. N.: Weight and length measurements of foetuses of Karakul sheeps and goats. Growth 1952, 16, 175-187.

Epstein, H. \& A. Herz: Fertility and birth weight of goats in a subtropical environment. J. agric. Sci. 1964, 62, 237-244.

Gjesdal, F.: Age determination of bovine foetuses. Acta vet. scand. 1969, 10, 197-218.

Lyngset, $O .:$ Studies on reproduction in the goat. I. The normal genital organs of the non-pregnant goat. Acta vet. scand. 1968a, 9, 208-222.

Lyngset, O.: Studies on reproduction in the goat. II. The genital organs of the pregnant goat. Acta vet. scand. $1968 \mathrm{~b}, 9,242-252$.

Richter, J. \& R. Götze: Tiergeburtshilfe. (Veterinary Obstetrics). Paul Parey, Berlin und Hamburg 1960.

\section{SUMMARY}

1. A total of $\mathbf{1 8}$ goats were ovariohysterectomized at different stages - 26 days to 145 days - of pregnancy.

2. The amniotic fluid increases from about $3.5 \mathrm{ml}$ at 30 days to $600-$ $1,000 \mathrm{ml}$ per foetus at birth.

3. At birth the amount of allantoic fluid is approximately $600-1,100$ $\mathrm{ml}$ and is to a small extent dependent on the number of foetuses.

4. The length of the foetus is about $1.4 \mathrm{~cm}$ at 30 days and $43 \mathrm{~cm}$ at 145 days, the lengthwise growth curve from the 30th day and onward being almost linear.

5. Hair follicles are visible around the 60th day and the eyes open between the 130th and 140th day.

6. The average length and weight of the goat kids at birth are 42.06 $\mathrm{cm}$ and $2.81 \mathrm{~kg}$ respectively.

7. The birth weight and length tend to increase with the increasing age of the dam.

8. The male does not appear to have any influence on the birth weight and length of the offspring. 


\section{SAMMENDRAG}

Undersфkelser over reproduksjonen hos geit.

VII. Drektighet og utvikling av foster, fostervæske og fosterhinner hos geit.

1. I alt 18 geiter ble ovarihysterektomert på forskjellige stadier 26 dager til 145 dager - i drektigheten.

2. Mengden av amnionsvæske $\varnothing \mathrm{ker}$ fra ca. $3,5 \mathrm{ml}$ ved 30 dager til $600-1.000 \mathrm{ml} \mathrm{pr}$. foster ved fødsel.

3. Ved fødsel varierer mengden av allantoisvæske mellom $600-1.100$ $\mathrm{ml}$ og mengden synes å være lite avhengig av antallet fostre.

4. Lengden av fosteret er ca. $1,4 \mathrm{~cm}$ ved 30 dager og ca. $43 \mathrm{~cm}$ ved fødsel. Fra 30 dager er kurven for lengdeveksten nærmest liniær.

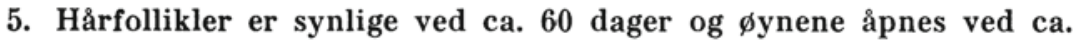
130 dager.

6. Gjennomsnittslengde og vekt av de nyfødte geitekje er henholdsvis $42,06 \mathrm{~cm}$ og $2,81 \mathrm{~kg}$.

7. Det synes å være en tendens til фkende vekt hos kjeene med $\emptyset$ kende alder hos moren.

8. Hanndyret synes ikke a influere på fødselslengden eller -vekten hos avkommet.

(Received March 25, 1970). 